\title{
Business Expediency, Contingency and Socio-Political Realities - A Case of Unplanned Mine Closure
}

\author{
M. Chaloping-March School of Philosophy, Anthropology and Social Inquiry, The University of \\ Melbourne, Australia
}

\begin{abstract}
Mine closure is an area where the mining industry can demonstrate its commitment to the principles of sustainability. Within the minerals sector, the emphasis though has been on the need to consider strategies and activities in advance. While it is essential that planning for mine closure is done at the earliest stage possible, certain cases, particularly in many developing countries, demonstrate that this is not always possible. On the ground, there is often a relatively short duration, if at all, between preparing closure plans and the actual closure of mine operations. This paper examines a case in which the key social actors in the mine closure process, mainly a mining company and a large community, were caught up in situations where they had to adopt innovations that are expedient. The actions of the company and the responses of the community were contingent on circumstances that could not have been predicted if mine closure was planned by the company several years ago, much less many decades ago. In a convoluted way, efforts at preventing previously 'abandoned' mine workings from impairment is tied to the social imperative of addressing people's need for livelihood. In turn, business viability can be ensured.

The paper contributes to understanding the complex socio-economic, political and business realities that shape the context of implementing protocols and principles of mine closure. On a higher plane, the paper demonstrates that planning for, and implementing, mine closure successfully does not simply require good legislation, financial guarantees, and mechanisms for monitoring and auditing. These are factors that indeed ensure a workable closure plan. However, an understanding of the complex institutional, economic, political and cultural milieu, within which closure principles, strategies and activities are realized, is paramount.
\end{abstract}

\section{Introduction}

Mining as an economic activity is ages old. However, the importance of attending to the different aspects of closing down mine operations has begun to emerge in mining policy and mine planning only in recent years (Peck et al., 2005). Within the minerals sector, the adoption of innovations is a response to the growing consciousness of public health and safety issues, rising public concerns about environmental pollution, and recognition of the value of environmental protection and continuing environmental stewardship. The purported aim of mine closure is to avert or minimize negative long-term environmental impacts, and "to create a self-sustaining natural ecosystem or alternate land use based on an agreed set of objectives" (ANZMEC and MCA, 2004).

In the continuing debate on the contribution of mining to sustainable development, there has been a growing recognition of the significant repercussions of mine closure on the socio-economic and cultural well-being of affected communities. Mine closure planning is regarded as a forward-looking strategy to subvert the occurrence of future problems at two levels: at the local community or region, and at the mining firm (Warhurst and Noronha, 2000). Within a locality, district or region where mining has been the major (if not lone) provider of employment and services, appropriate mine closure strategies can help prepare communities and local governments for the eventual loss of major sources of income, i.e. mine employment and the associated businesses. On the part of the mining firm, undertaking mine-closure planning anticipates problems such as the need for costly clean-up and possible liabilities that might emerge from related environmental or social concerns.

Mine closure is an area where the mining industry can demonstrate its commitment to the principles of sustainability. Within the minerals sector, the emphasis though has been on the need to consider strategies and activities in advance. Many authors have stressed the idea that planning for mine closure must be 
undertaken as early as during the feasibility stage for new projects. The arguments and suggestions can be summed up as, what Hoskin (2002) called, the "21st century approach" which aims to avoid negative social and environmental legacies, but promote "an economically viable, environmentally sensitive, socially responsible industrial sector". Through such an approach, mining, as an industrial sector, is envisioned to produce "sustainable and decentralized benefits to foster other activities and increase capacities in the communities".

Guidelines for mine-closure planning are often couched in technical-managerial terms, almost with the promise that success is ensured as long as early planning is undertaken, in addition to ensuring that the fundamentals are in place, e.g. compliance with mine closure legislation, allocation for rehabilitation funds, and an effective mechanism for auditing or monitoring.

The emphasis on planning for mine closure at the earliest stage possible, while essential, discounts the reality - especially in many developing countries - that in many cases, there is often a relatively short duration, if at all, between formulating closure plans and the actual closure of mine operations. On the ground, the prescriptions and formulations for undertaking the 21st century approach to mine closure remains far-fetched due to real and complicated, but not unusual, circumstances which remain inadequately understood. First, there are unplanned closures that happen suddenly for reasons that can range from major natural disasters to crippling industrial strikes or civil wars. Second, there are anticipated closures where planning for them had begun only a few years before actual closure. To appreciate the complexity of social problems that are associated with mine closure and post-mine scenarios, it is important to recognize that there are these cases of unplanned or 'short-planned' closures. In addition, it is critical to acknowledge the socio-political setting within which these cases are embedded.

Mine closure is more than a managerial-technical-engineering aspect within the life cycle of a mine. It is a social episode in the lives of individuals, households, families, communities, and local governments. However, little study has been carried out on undertaking mine closure within this context. There is an extreme dearth of research on social and economic settings where mine-closure planning was not incorporated into the broad cycle of mine operation, the strategies that evolve to address problems, and the socio-political setting within which remedial practices are undertaken.

This paper examines a case in which the key social actors in the mine closure process, mainly a mining company and a large community, were caught up in situations where they had to adopt innovations that were expedient. The actions adopted by the company and the responses of the community were contingent to circumstances that could not have been predicted if mine closure was planned by the company several years ago, much less many decades ago.

To provide a structure for discussion, the paper first presents a profile of Benguet Corporation, the oldest mining company in the Philippines, which is still in operation. This is followed by a description of smallscale mining, an economic activity that has shaped the nature of company relations with the community that emerged and grew in tandem with the operations of the Acupan mine. Both will serve as backdrop for discussing the reopening of the mine as part of the company's efforts to ensure business viability as well as deal with the community's need for livelihood. The paper then looks into the company's rehabilitation strategies of old mine workings and disturbed landscapes.

\section{Brief history and company profile}

Benguet Corporation was once the largest gold and chromite producer, and a top copper producer in the Philippines (BC, 1985; 1986; 1987; 1988; 1989). From the 1900 s until the present, Benguet Corporation has controlled a vast area of mineral lands in the municipality of Itogon. The company-owned lands have been subsumed under one subsidiary which used to be called Benguet Gold Operations (BGO), constituted by a cluster of several gold mines. The company has impacted on mainly three large mining areas: Antamok, Acupan and Balatoc. Administratively, all three places are within the municipality of Itogon. This paper is concerned mainly with Acupan and Balatoc.

Benguet Corporation was incorporated on 24 June 1903, and registered on 12 August 1903 as a joint-stock company (Ramos, 1988). The company commenced mining and milling operations in Antamok in 1906. Antamok is an old place that was traditionally known for gold mining long before colonialists arrived in the 
Philippines in the 1500s. The Antamok mine was the first major modern mining operation in the Philippines and the first successful mining venture (BC, 2005c). In 1909, the company established another mine in Acupan, a locality adjacent to Antamok. The Acupan mine started commercial operations in 1927 and was a major underground gold operation, with a long working life. Until the mine's closure in 1992, Acupan produced at least 5.54 million ounces (172 tons) of gold from about 21.7 million tons of ore (BC, 2002a). A mill to process ores from both Acupan and Antamok mines was put up in Balatoc, another locality contiguous to Acupan.

As previously stated, the Acupan mine ceased operation in 1992 as a result of a combination of events. To a large extent, the closure was triggered by the decline of metal prices in the international market. This was exacerbated by major damages caused by a powerful earthquake that struck the Northern Philippines in 1990. This caused flooding of underground work areas, particularly three major levels below the drainage system. In addition, the company faced mounting tensions with the workers' union. Furthermore, community protests had been growing against the company with regard to its open pit operations in Antamok ${ }^{1}$.

\section{Small-scale mining in Acupan}

As used in this paper, small-scale mining refers to the economic activity that involves individual miners or small groups of miners, as opposed to the enterprise of large-scale corporate mining. A small-scale mining group usually consists of kinfolk and, in other instances, a number of non-kin members. Small groups may include four to six individuals while large groups may include as many as 70. Small-scale mining encompasses basically two forms: pocket mining and gold panning. Pocket mining is so called owing to the method in which miners trace gold veins by entering holes or pockets of the earth. It is also known in the Benguet Province and the larger Cordillera region as camote mining in reference to digging for camote (sweet potato). Meanwhile, gold panning, which is usually carried out by individual household members, and not necessarily groups of miners, involves collecting some naturally-occurring gold from alluvial deposits along riverbanks (Chaloping, 1991). For the purpose of clarity, the more specific terms of pocket mining and gold-panning are used in this paper. The term small-scale mining is employed when referring to both forms.

Like Antamok, Acupan and Balatoc were mentioned frequently in Spanish accounts as sites of gold diggings and sources of fine gold that the highlanders traded with lowlanders in Luzon. Acupan-Balatoc ${ }^{2}$ became a $^{2}$ huge mine camp ${ }^{3}$ by the 1970 s, populated by mine workers who had been recruited by Benguet Corporation to meet workforce requirements for mine operation. Over many years, the large workforce established their families within the mine camp. The population of Acupan-Balatoc in 1990, two years before the mine closed down, was 15,000; this represented 2,780 households ${ }^{4}$.

Throughout the many decades of the Acupan mine's operations, employment with the mine had been the major source of income for thousands of people. By the late 1970s, small-scale mining started as a supplementary economic activity in the locality. However, people could not carry it out openly. The company prohibited both gold panning along the river and any pocket mining on the hills. Throughout the 1970s, there were only two pocket mining tunnels within Acupan. These were located relatively faraway from the assiduous watch of company security guards.

By the end of 1983, small-scale mining spread to more areas within the Acupan mine camp as the price of gold in the international market surged. More and more portals opened as scores of small-scale miners continued their activities clandestinely. Between 1986 and 1987, the number of small-scale miners multiplied to the tens of hundreds. This also reflected the country's difficult economic situation as more families could barely afford consumer goods due to soaring prices. Driven by economic difficulties, thousands of people

1 The Antamok mine had been an underground operation until the 1980s, the period when the company shifted to large-scale open pit mining due to the depletion of high-grade gold ores underground.

2 Considering that Acupan and Balatoc are contiguous settlements of workers for the company, I refer to the larger community as 'AcupanBalatoc'. Reference to one or the other singly is made when necessary.

3 The mine camp, under the direct administration of the company, included facilities for housing, commerce, education, medical care and recreation. Under strict company rules, only employees and their families were considered the bonafide residents in the mine camp.

4 This information was provided by the local council (i.e. Barangay Virac, the politico-administrative unit comprising Acupan-Balatoc). Available data collected in 2003 indicated that the population of Acupan-Balatoc stood at 4500, a much-reduced number following the retrenchment of workers when mine operations ceased in 1992. 
chose to undertake small-scale mining. Scores of tunneling sites opened up in several vicinities within Acupan. As if rising prices of basic commodities were not bad enough, thousands of mine employees had lost jobs as the company reduced its more than 6000-strong BGO workforce in 1989. Due to bleak prospects for metal prices, the company had undertaken several rounds of retrenchment starting in 1989 (Rowe, 1992). With the loss of employment, small-scale mining in Acupan surged in the 1990s.

Benguet Corporation has remained the owner of vast tracts of land in Itogon, including many areas where small-scale miners still carry out their activities today. As such, small-scale miners are considered illegal in the sites where they are working. Their status is based on their lack of company consent, in the ultimate form of a permit to mine on the site 5 .

In 1991, a new law governing small-scale mining was enacted, the Republic Act 7076 (People's Small-Scale Mining Act of 1991). A significant introduction in this law is its creation of the Provincial/City Mining Regulatory Board (PMRB) as the government's arm to regulate and issue permits to small-scale mining activities. Many small-scale miners consider this law ineffectual because Itogon remains covered by mining claims and watersheds. As the legalization of small-scale mining continues to be debated, small-scale miners carry on with their activities in areas where it is possible and during times when they can. They consider the requirements for acquiring a permit onerous. The requirements include the consent of claim owners for small-scale miners to work in a site. The expenses and time to prepare documents are another matter. A geological survey, a technical mining plan, and an area-status clearance from the Mines and Geosciences Bureau (MGB) are among the documents needed to prepare and submit to PMRB.

At present, however, most small-scale miners in Acupan no longer see their lack of permit as a big problem because Benguet Corporation has stopped prohibiting their mining activities. The majority of small-scale miners share the view that the company has become more enlightened in accepting that it could not go on protecting company lands indefinitely when there are hundreds of people who are without work and desperate to survive. Many others observed that the company had actually taken the core wealth of Acupan so small-scale miners are now being tolerated to work on small veins.

\section{Re-opening previous mine workings after closure}

Following the retrenchment of thousands of employees from the late 1980s to the early 1990s, AcupanBalatoc saw an exodus of people. But even with the mass departures, a large number of the retrenched employees found ways to stay in Acupan-Balatoc. With no alternative employment, it was not surprising that they joined the hundreds of people who had been conducting pocket mining in different portions of the hills in Acupan. Thus, adits had proliferated as the number of pocket miners had more than doubled.

In Balatoc, where most company installations had remained after the retrenchment, the company found it imperative to secure its ventilation portals because some pocket miners had been entering the company's underground work areas illegally. However, many groups of pocket miners were able to encroach into company's underground workings through a few surface inlets. It was becoming extremely difficult for the company to fully guard its property as diggings were taking place in many areas.

A few senior officers within the company recognized that the illegal entry into company lands could hardly be stopped. Thus, these officers considered engaging in a partnership with small-scale miners. There were two reasons for considering the idea of forging a working relationship with small-scale miners. Firstly, the partnership was workable and pragmatic. Establishing a sharing venture with the small-scale miners could be the only way for Benguet Corporation to continue mining because the option of re-hiring employees was not financially feasible. Secondly, the necessity to forge better relations with the community was the only way for both parties to coexist. The company managers understood that many people in the area had no

5 Consent to mine in an area is required by law for the issuance of mining permits. The first law pertaining to small-scale mining is the Presidential Decree 1899 (Establishing Small-Scale Mining as a New Dimension in Mineral Resources). It was issued in 1984 and aimed to provide the legal basis for issuing licences and permits to small-scale miners. The permitting requirement for small-scale mining is a complicated issue. Some leaders in the small-scale mining sector consider the Presidential Decree 1899 as impossible to apply in Itogon or elsewhere. Considering that Itogon is covered by binding and existing claims of mining companies and individuals, there is no way for small-scale miners to gain 'legality' because claim owners of mineralised lands are not expected to grant consent for small-scale miners to undertake their activities. 
alternative livelihood and there was no way to stop people from carrying out their mining activities, prohibited though they may have been.

Adopting the name Acupan Contract Mining Project (ACMP), the company-community partnership started in 1999, involving about 700 to 800 small-scale miners who were to carry out production activities through a contract arrangement with the company. The official re-opening of the project was in December 2001. The company intended the ACMP to be a "low-capital, low-cost venture" (BC, 2002b). Commercial production began in 2002. The company reopened four levels of its Acupan underground workings.

The method employed is camote mining which pocket miners are most familiar with, i.e. excavating narrowvein deposits to collect ores. The company spent around PhP15 million ${ }^{6}$ for purchasing and installing a 50 TPD (tons per day) Carbon-In-Leach/Carbon-In-Pulp plant to provide central processing services. By providing a centralized-ore-processing unit for all small-scale miners, Benguet Corporation claims that it makes possible for the compliance to environmental laws with regard to processing (BC, 2003b).

The ACMP started commercial operations in 2002 with the implementation of the first mining contracts. The partnership was on a royalty scheme in which the contract small-scale miners carried out the underground work and the company received some royalty. In mid 2003, however, the scheme shifted to production sharing: the ore that was mined is shared between the two parties in which 60 per cent is allotted to the small-scale miners and 40 per cent to the company. Benguet Corporation plans to expand the ACMP's current mill capacity, with a target of 100 TPD throughput by 2009 having been set (BC, 2008).

While the ACMP operates in Balatoc, hundreds of pocket miners have continued, until the present, to undertake mining in the hills of Acupan. The access and prerogative to work in a small-scale mining site, although such sites are acknowledged as located within the mineral lands of Benguet Corporation, has been 'acquired' by individuals and groups on the basis of being the first to open the portal and dig the tunnel. Individuals and groups have, over time, invested labor and other resources in their tunnels such that it becomes almost common knowledge among residents in the area that the tunnel is maintained by the individual or group. With Benguet Corporation halting its relentless pursuit of small-scale miners, the latter has interpreted that the company is tolerating their mining activities.

\section{Old mining facilities for tourism and income generation}

The turbulent business climate in the 1990s prompted Benguet Corporation to restructure its operations and consolidate its resources. It strategically broadened its businesses beyond the principal interests of mineral and mining exploration. In particular, it has engaged in projects such as ecotourism, real estate development, and bulk water supply. The company has maintained its interests in allied industries such as steel casting, trucking and warehousing, trading, engineering and construction services.

Five years after the Acupan mine was closed, the company converted its mining facilities in Balatoc into what the company has been promoting as the Benguet Mines Tourism Village. The company considers the project as 'the first and only mining attraction' in the country. The project has sought to present the AcupanBalatoc mine as part of the gold mining heritage of the Cordillera ${ }^{7}$.

The Benguet Mines Tourism Village includes a tour to the underground Vegas tunnel, a visit to the mines museum showcasing rock samples of gold in its native form and the early gadgets used by traditional miners. An added feature is the Balatoc Lake, one of the company's former tailings dams, for fishing and canoeing activities. The company amenities that have remained, such as the Villaluna Building, cottages, a conference hall, dormitory, swimming pool, billiard hall, and table tennis facility, are advertised for out-of-town functions. For its income-generating potential, Benguet Corporation's tourism promotion has been supported by the municipality of Itogon, the province of Benguet, the Department of Environment and Natural Resources, and the Department of Tourism.

6 Approximately US $\$ 400,000$.

7 The Cordillera is a mineral-rich region where gold mining and gold trading forms a significant part of the inhabitants' traditional way of life, particularly in the Benguet Province. The region is located in the northern part of Luzon, the largest island in the Philippines. 
Many people in Acupan-Balatoc share the view that the Benguet Mines Tourism Village is a deliberate and clear gesture from the company that it has no intention of leaving Acupan-Balatoc. The company, itself engaged in real estate development projects, is even looking into the development of Balatoc as a new satellite town to Baguio City ${ }^{8}$ (BC, 2002b). Within the company, the Task Force New Balatoc was created to oversee this project. To date, the task force has already completed the interim land use and zoning plan. The Benguet Mines Tourism Village is considered part of the envisioned 'New Balatoc' (BC, 2005a).

\section{Land in Itogon}

Even though sections of the company claims were relatively mined out, Benguet Corporation has remained in control of vast areas of land within Itogon municipality. Most of the company's mining claims are company-owned, while a few are under contract with various claim owners. The Acupan mine, in particular, covers a total area of $15.24 \mathrm{~km}^{2}$. It consists of 223 mining claims acquired through several laws, i.e. the Commonwealth Act $137^{9}$, Presidential Decree $1214^{10}$ and Presidential Decree $463^{11}$ (BC, 2002a). Many of the company's claims are patented, acquired under Philippine Bill of 1902 during the American regime, which means that the company has absolute ownership of both surface and underground ${ }^{12}$ land.

Land use and land classification have been perennial issues to residents and local government officials in the Itogon municipality. Benguet Corporation, being the claim owner of patented and patentable lands, has absolute ownership over surface and underground. However, within most of these lands, thousands of people have become occupants. Throughout many decades, what were since categorized as mining claims have ossified into 'mineral lands', regardless of whether or not mining operations within these lands have stopped.

The local government of Itogon asked the MGB to determine which mineral lands in Itogon - whether company owned or leased from other claim owners - are already mined out, inactive mining claims, or not economically feasible to mine. Itogon residents have been hoping that in terms of a reclassification of lands, those that are classified as 'mineral lands' would be reduced in the municipality's land-use map to enable the enlargement of other lands such as those for housing. In mid 2004, however, the Department of Environment and Natural Resources (DENR) declared that mining firms, which may have shut down their operations, "still have proprietary rights over the lands that they mined and may use these in new business ventures" (Sun Star Baguio Online, 2006). This development dampens the efforts of the Itogon local government to reclaim portions of lands that were patented by the American colonial government in favor of Benguet Corporation.

\section{The bulk-water-supply project}

Benguet Corporation prided itself in being the first in the country's minerals industry to convert its minedout open pit in Antamok to a giant water reservoir. In August 2005, the Baguio Water District (BWD) awarded the company the 25 year contract to service the 300,000 population-dense city of Baguio. Costing US\$60 million, the Bulk Water Supply Project (BWSP) would involve the distribution of about $50,000 \mathrm{~m}^{3}$ of treated water daily to Baguio. The water would be sourced from the Antamok River, which would then fill up the reservoir, the company's mined-out 440-vein open pit. The project was targeted to operate supposedly by mid 2008 (BC, 2006).

The open pit Antamok gold mine had operated for six years until it shut down in 1998 for reasons associated mainly with shortage of funds as a result of interrelated factors. Initially, Benguet Corporation had planned

8 Baguio city is the most-highly-urbanized place in northern Luzon. It is also the location of major tertiary education institutions and business/commercial facilities in the northern Philippines.

9 Commonwealth Act No. 137, otherwise known as the Mining Act of 1936, was actually the first major mining law that would stay for about 38 years until it was amended by Presidential Decree 463.

10 Presidential Decree 1214, issued by then President Marcos on 14 October 1977, required all locators under the Act of Congress of 1 July 1902 to secure mining lease contracts under the provisions of P.D. No. 463 involving their patentable mining claims.

11 Presidential Decree 463 (Mineral Resources Development Decree) is also known as the Mineral Resources Development Act and was enacted on 17 May 1974. It governed the old system of exploration, development, and utilisation of mineral resources through 'license, concession, or lease'. As amended by PD 1385 and PD 1677, Presidential Decree 463 provides that all mineral deposits in public or private lands within the territorial limits of the Philippines belong to the state.

12 Section 27 of the Philippine Bill of 1902 provided that the holder of a mineral claim shall be entitled to all minerals which may lie within his claim. 
to backfill the open pit as part of its decommissioning scheme. This plan, which had not taken off at all after almost a decade, changed. The company would no longer push through with the backfilling of the gaping pit. In justifying the change, Benguet Corporation asserted that 'the conversion of the open pit to a water reservoir, and development to watershed of the adjacent area, are consistent with the policy of the DENR for sustainable management of resources'. The company also cites that, in the certification issued on July 31, 2004 by the MGB, the project was approved as a preferred mine rehabilitation option, which is in accordance with the policy of MGB, that "land disturbed by mining be rehabilitated to a more productive and beneficial land use" (BC, 2005b). The company stressed that the project is "a model of mine rehabilitation and alternative land use in the country" (BC, 2006).

The bulk water project has invited mounting opposition from concerned sectors, particularly the residents of Itogon and Baguio. The main apprehension of Itogon residents is that their current water sources might be completely depleted by Benguet Corporation, given the $50,000 \mathrm{~m}^{3}$ capacity that the company is required to deliver to Baguio on a daily basis. On the part of the Baguio consumers, their key concern is the potability and safety of water, in addition to the price that end consumers will be paying. Questions have been raised about water quality, given that the company's open pit mine is alleged to contain heavy metals such as lead, cadmium, magnesium and mercury. Another critical issue raised pertains to the absence of consultation by the company with the residents of Itogon, whose concerns and anxieties remain unaddressed. These include the need for an appropriate post-mine land use, the implications of the water reservoir for small-scale mining activities, and residents' water rights vis-à-vis commoditization of the resource by a private entity (CPA 2004a; 2004b; Northern Dispatch, 2004; 2005a; 2005b; Opiña, 2005).

The opposition appears to have contributed to halting the Bulk Water Supply Project. In September 2007, the BWD issued a resolution that "resolved to terminate the bulk water supply contract negotiation" with Benguet Corporation and "to scrap the project". The resolution indicated the reasons as being "the irreconcilable differences of the parties on the contract provisions of parametric formula and rate rebasing, among others'. The BWD was concerned about the affordability and acceptability of the water tariff that was going to be imposed by Benguet Corporation on the end consumers. On the other hand, the company pointed out the delay in the implementation, and its effect on the viability of the project, as justification for the contract provisions. Benguet Corporation also requested the BWD to conduct a public hearing on these issues of contract provision, which the BWD deemed premature. On November 2007, Benguet Corporation received a BWD resolution denying the former's request for reconsideration. In response, Benguet Corporation filed a case against BWD, which is now pending at the Regional Trial Court of Baguio City (BC, 2008).

\section{Conclusion}

This paper demonstrated the social and political realities that influence the formulation and implementation of principles of mine closure. Members of the community that depended on the operations of the mine did not have the opportunity of contributing to any planning by the mining company for a pre-mine closure or transition scheme, as the company itself did not have any pre-closure plan. The Acupan mine closed down in 1992, a time when the Mining Act of 1995, which requires a company to address the social and environmental repercussions of closure, had not been enacted. After almost a decade of its Acupan gold mine in a non-operational state, the company found it unavoidable to reopen the mine mainly due to threats of asset loss, in particular the extraction of ores from company-owned lands. What prompted people to engage in mining within the company's private lands was the desperation to survive, itself a repercussion of sudden unemployment. What has happened thus far includes adoption by the company of mechanisms contingent to its corporate goal of generating profits and remaining viable. However, actions and decisions towards corporate goals are shaped by other social factors such as those that oppose projects and those with whom the company forges contracts.

The paper argues that implementing mine closure requires acknowledgement and consideration of the historical development of the affected community. The district of Itogon has had a long tradition of mining. The mine-site camp of Acupan-Balatoc was created by Benguet Corporation's history of labor recruitment and mineral production. As mineral production carried on for a century, the company modified not only the physical landscape of the community but also structured the social relations of people. These have molded the nature of the company-community relationship. Ultimately, they influence the types of challenges left to 
the community and local government, two constituencies who are the end recipients of undesirable legacies from mining.

Within discussions on sustainability and mineral development, the theme of mine closure has begun to include how a mining company should leave the place of its operation. Concerns are raised about not only the physical landscape that has been degraded but also the social landscape that confronts an uncertain postmine future. Critical resource issues such as land use and land tenure further complicate economic and social difficulties associated with mine closure. In terms of addressing environmental degradation, many mining companies presently possess the personnel and technical resources to carry out appropriate programmes. However, the processes are predominantly technical. It is in addressing the socio-economic and cultural issues, where approaches need to extend beyond engineering-managerial frameworks.

Planning for, and implementing, mine closure successfully does not simply require good legislation, financial guarantees, and mechanisms for monitoring and auditing. These are factors that certainly define a workable closure plan. However, an understanding of the complex institutional, economic, political, and cultural milieu within which closure principles, strategies and activities are carried out, is paramount. Mine closure activities are carried out within a "social field" in which various resources such as materials, information, technology, and sets of relationships are distributed (Long, 2001). The process of implementing mine closure involves multiple parties whose respective interests may differ but may, under certain circumstances, converge. As a key player, a mining company pursues what is expedient for its corporate goals but contingent to socio-political realities.

\section{Acknowledgements}

This paper forms a part of my $\mathrm{PhD}$ dissertation for which an ethnographic fieldwork was carried out in mid 2003, September 2004-May 2005, with a few more interviews in 2006-2007. The author thanks key informants for their indulgence in answering my queries. In Acupan, Mr Camait Cawaren and his family kindly provided me with accommodation. In Balatoc, Barangay, Captain David Ecwasen very kindly escorted me around the community. At Benguet Corporation, Mr. Marcelo Bolaño, Engr. Angelito Gomez, Engr. Jacob Melecio, and Engr. Ernesto Manipon generously gave up their valuable time to speak with me. Similarly, Mayor Mario Godio and Councillor Michael Tauli at the municipal government of Itogon were very kind to accommodate me for interviews. The many pocket miners in Acupan and several contract miners of the ACMP graciously shared profound insights about life through and in mining, with their entertaining and inspiring accounts.

\section{References}

ANZMEC and MCA (Australia and New Zealand Minerals and Energy Council and the Minerals Council of Australia) (2004) Strategic Framework for Mine Closure. Canberra: ANZMEC - MCA, accessed 2007-04-07. http: //www.ret.gov.au/Documents/Strategic_\%20Framework_\%20for_\%20Mine_\%20Closure20040416120518.pdf.

Barangay Council of Virac (2005) Barangay Profile of Virac (unpublished). Virac, Itogon, Benguet.

BC (Benguet Corporation) (1985) Benguet Corporation and Subsidiaries Annual Report 1985. Benguet Corporation.

BC (Benguet Corporation) (1986) Benguet Corporation and Subsidiaries Annual Report 1986. Benguet Corporation.

BC (Benguet Corporation) (1987) Benguet Corporation and Subsidiaries Annual Report 1987. Benguet Corporation.

BC (Benguet Corporation) (1988) Benguet Corporation and Subsidiaries Annual Report 1988. Benguet Corporation.

BC (Benguet Corporation) (1989) Benguet Corporation and Subsidiaries Annual Report 1989. Benguet Corporation.

BC (Benguet Corporation) (2002a) Acupan Gold Mine. http://www.benguetcorp.com/html/Acupan\%207-5-02.pdf, accessed 2006-11-11.

BC (Benguet Corporation) (2002b) Benguet Corporation 2001 Annual Report.

BC (Benguet Corporation) (2003a) 2003 First Quarter Report Benguet Corporation and Subsidiaries.

BC (Benguet Corporation) (2003b) Benguet Corporation 2002 Annual Report.

BC (Benguet Corporation) (2005a) Benguet Corporation 2004 Annual Report (SEC Form 17-A), accessed 2007-01-11. http://www.benguetcorp.com/html/BC\%202004\%20Annual \%20Report.pdf.

BC (Benguet Corporation) (2005b) Bulk Water Supply Project Notice of Award, accessed 2007-04-23. http://www.benguetcorp.com/html/Bulk\%20Water\%20Project.htm.

BC (Benguet Corporation) (2005c) A Century of Facts (IPages\The Company\The Company 1.htm) On Benguet Corporation The Natural Resource Company (Compact Disk). Makati City, Philippines: Benguet Corporation.

BC (Benguet Corporation) (2006) Benguet Corporation 2005 Annual Report (SEC Form 17-A), accessed 2006-12-01. http://www.pse.com.ph/html/ListedCompanies/pdf/2006/BCB_17A_Dec2005.pdf. 
BC (Benguet Corporation) (2008) Benguet Corporation 2007 Annual Report (SEC Form 17-A), accessed 2008-0-25. http://www.benguetcorp.com/html/BC\%202006\%20Annual\%20Report SEC\%20Form\%2017A.pdf.

Chaloping, M.M. (1991) Towards Sustainability of Household Well-Being: Labor Allocation Between Goldpanning and Rice Farming in Dalupirip, Itogon, Benguet. Unpublished Master of Arts Thesis University of the Philippines, Baguio.

CPA (Cordillera Peoples Alliance) (2004a) Metro Baguio Consumers Movement Position Paper on Metro Baguio's Water Crisis, 24 July 2004, accessed 2007-01-31. http://www.cpaphils.org/campaigns/mb-consumers_stmt 41020.htm.

CPA (Cordillera Peoples Alliance) (2004b) Apit Tako on Struggle for Water Resources: Water War? 31 July 2004, accessed 2007-01-02. http://www.cpaphils.org/campaigns/water-war_4731.htm.

Hoskin, W.M.A. (2002) Mine Closure - The 21st Century Approach Avoiding Future Abandoned Mines. CEPMLP Online Journal, accessed 2003-12-03, from http://www.dundee.ac.uk/cepmlp/journal/html/vol12/article1210.htm.

Long, N. (2001) Development Sociology: Actor Perspectives. Routledge, London and New York.

Northern Dispatch (2004) BC, PBAC snub council hearing on bulk water Itogon folk dismayed. 19 December 2004 , accessed 2007-05-02. http://www.nordis.net/news/2004/ndw041219/ndw041219_01bulkwater.htm.

Northern Dispatch (2005a) BWD opens lone bidder's last envelopes. 16 January 2005, accessed 2007-05-02. http://www.nordis.net/news/2005/ndw050116/ndw050116_06bulkwater.htm.

Northern Dispatch (2005b) BC's water unsafe - Itogon elders. 14 August 2005, accessed 2007-05-02. http://www.nordis.net/news/2005/ndw050814/ndw050814_05bwsp.htm.

Opiña, R. (2005) Itogon folks continue to oppose water project, accessed 2007-05-02. http://www.sunstar.com.ph/ static/bag/2005/08/09/news/group.itogon.folks.continue.to.oppose.water.project.html.

Peck, P., Balkau, F., Bogdanovic, J., Sevaldsen, P., Skaalvik, J.F., Simonett, O., Thorsen, T.A., Kadyrzhanova, I., Svedberg, P. and Daussa, R. (2005) Mining for Closure: Policies and Guidelines for Sustainable Mining Practice and Closure of Mines: United Nations Environment Programme (UNEP), United Nations Development Programme (UNDP), North Atlantic Treaty Organization (NATO), and Organization for Security and Cooperation in Europe (OSCE). Accessed 2008-03-30, from http://enrin.grida.no/environment-and-security /mining_src.pdf.

Ramos, P.P. (1988) American Business in the Philippines: The Sociocultural Impact of Benguet Corporation. Unpublished Dissertation for Doctor of Philosophy (American Studies), University of Hawaii, Honolulu. Retrieved 31 October, 2007, from ProQquest Digital dissertation database (Publication No. AAT 9120521).

Rowe, M.R. (22 December 1992) Cost squeeze raps Philippines mining - Brief Article (American Metal Market), accessed 207-01-17. http://calbears.findarticles.com/p/articles/mii_m3 MKT/is_n246_v100/ai_13264604.

Sun Star Baguio Online (2006) Agency appeals to give idle mines to small-scale miners", accessed 2007-01-29. http://www.sunstar.com.ph/static/bag/2006/11/15/bus/agency.appeals.to.give.idle.mines.to.small.scale.miners.ht $\mathrm{ml}$.

Warhurst, A. and Noronha, L. (eds) (2000) Integrated environmental management through planning to closure from the outset: the challenges. Environmental Policy in Mining: Corporate Strategy and Planning for Closure. Lewis Publishers, Boca Raton, London, New York and Washington D.C., pp. 13-32. 
